\title{
DETERMINING OF PLASMA BIOCHEMICAL PARAMETERS ACCORDING TO DIFFERENT REPRODUCTIVE PERIODS IN THE POPULATION OF Testudo graeca (ÇANAKKALE, TURKEY)
}

\author{
GÜLEN, E. - GÜL, Ç.* \\ Department of Biology, Faculty of Arts and Sciences, Çanakkale Onsekiz Mart University, \\ Terzioğlu Campus, 17100 Çanakkale, Turkey \\ *Corresponding author: \\ e-mail: gulcigdem@comu.edu.tr; phone:+90-286-218-0018/2736; fax: + 90-286-218-0533
}

(Received 21 ${ }^{\text {st }}$ Feb 2018; accepted $21^{\text {st }}$ May 2018)

\begin{abstract}
In this study, some biochemical parameters (glucose, urea, calcium, triglyceride, cholesterol, creatinine, uric acid, total protein, iron, albumin, phosphorus, H.D.L., magnesium) hemoglobin and hematocrit depending on the pre-reproductive and reproductive periods and sex were determined in a total of 20 Testudo graeca specimens in the Çanakkale (Turkey). For the biochemical parameters, $0,5 \mathrm{ml}$ of blood was collected from the scale in the lateral ligament of the neck with a 5-ml aspirating syringe. The blood was transferred into the biochemical tubes and centrifuged; the plasma part was separated and was measured by spectrophotometer. In conclusion, plasma biochemistry parameters were determined on sexrelated pre-reproduction and reproduction periods in T. graeca. When comparing the pre-reproductive and the reproductive period in terms of glucose, uric acid and iron values, statistical differences were found in the females. It was determined that cholesterol values of males were significantly different between periods. In the females, glucose value was found high in the pre-reproductive period and uric acid and iron values were high in the reproductive period. Cholesterol values of males were found high in the pre-reproductive period. Iron levels in the pre-reproductive period were significantly different between males and females.
\end{abstract}

Keywords: Testudo graeca, plasma biochemistry, hematology, reproductive period, Turkey

\section{Introduction}

Reptiles have different adaptations to terrestrial life that are not usually found in other animal species. The turtle group, which includes species living on land, in freshwater, and in marine ecosystems and also has varying morphological and physiological characteristics is one of the important groups among reptiles (Godfrey and Campbell, 2002). Plasma biochemistry studies have been used to support and extend the results of studies in the field of hematology, as animal populations, physiology, guide the determination of the environmental status of the habitat in which they live (Jacobson et al., 1991; Raphael et al., 1994; Lopez-Olvera et al., 2003).

For all these reasons, biochemical analyses of blood plasma are an important method for finalizing the health of many animal species and in recent years, reptile-related hematology and plasma biochemistry studies have been increasing rapidly.

There are many studies on blood cells and clinical hematology (Marks and Citino, 1990; Dickinson et al., 2002; Lopez-Olvera et al., 2003; Tosunoğlu et al., 2005; Hamooda et al., 2014; Bielli et al., 2015) and plasma biochemistry associated with Testudo species (Gilles-Baillien, 1969, Lopez-Olvera et al., 2003, Dickinson et al., 2002, Marks and Citino, 1990, Scope et al., 2013, Hamooda et al., 2014; Özdamar, 2014, Hetenyi et al., 2016). Mediterranean Spurred Tortoise, T. graeca is classified in 
the vulnerable species category according to IUCN (Red list) criteria. It is spread in all suitable habitats (areas with less vegetation) in Çanakkale province (Tosunoğlu et al., 2017). Since $T$. graeca is an endothermic species, it may be affected by environmental conditions and external factors, as well as many internal and external factors affecting its blood parameters. Studies on hematology (Tosunoğlu et al., 2005), and plasma biochemistry (Hamooda et al., 2014) are very limited in T. graeca species. Tosunoğlu et al. (2005) have established reference intervals for blood cell measurements and clinical hematology parameters in Testudo hermanni and T. graeca species. Hamooda et al. (2014) conducted a study to determine sexually and seasonally related changes in plasma biochemical values of $T$. graeca species, which are spread in Libya.

There is no study about plasma biochemistry related to sex and different periods on T. graeca species which can be found around our country.

The purpose of this study is the determination of parameters of plasma biochemistry (glucose, urea, creatinine, calcium, albumin, cholesterol, total protein, uric acid, phosphorus triglycerides, magnesium, iron, HDL-cholesterol, hemoglobin and hematocrit) related to the sex (female-male) and different periods (pre-reproduction and reproduction period) of $T$. graeca, and the determination of reference intervals. It is also aimed to determine whether all parameters differ between pre-reproduction and reproduction period and between male and female individuals.

\section{Materials and Methods}

Çanakkale region is located in northwestern Turkey, and T. graeca samples used in this study were collected from mountainous areas around Bayramiç $\left(39^{\circ} 46^{\prime} 33.2^{\prime \prime} \mathrm{K}\right.$, $26^{\circ} 46^{\prime} 24.4^{\prime \prime}$ D, Altitude: 239 m), Lapseki (40 14' 50.8" N, 26 47' 13.9" E, Altitude:

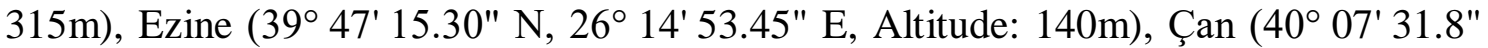
$\mathrm{N}, 26^{\circ} 31^{\prime} 22.9^{\prime \prime} \mathrm{E}$, Altitude: 60m) and city center $\left(40^{\circ} 06^{\prime} 55.0^{\prime \prime} \mathrm{N}, 26^{\circ} 25^{\prime} 28.4^{\prime \prime} \mathrm{E}\right.$, Altitude: $117 \mathrm{~m}$ ) (Fig. 1). In all of these localities, species were observed in open areas with low vegetation.

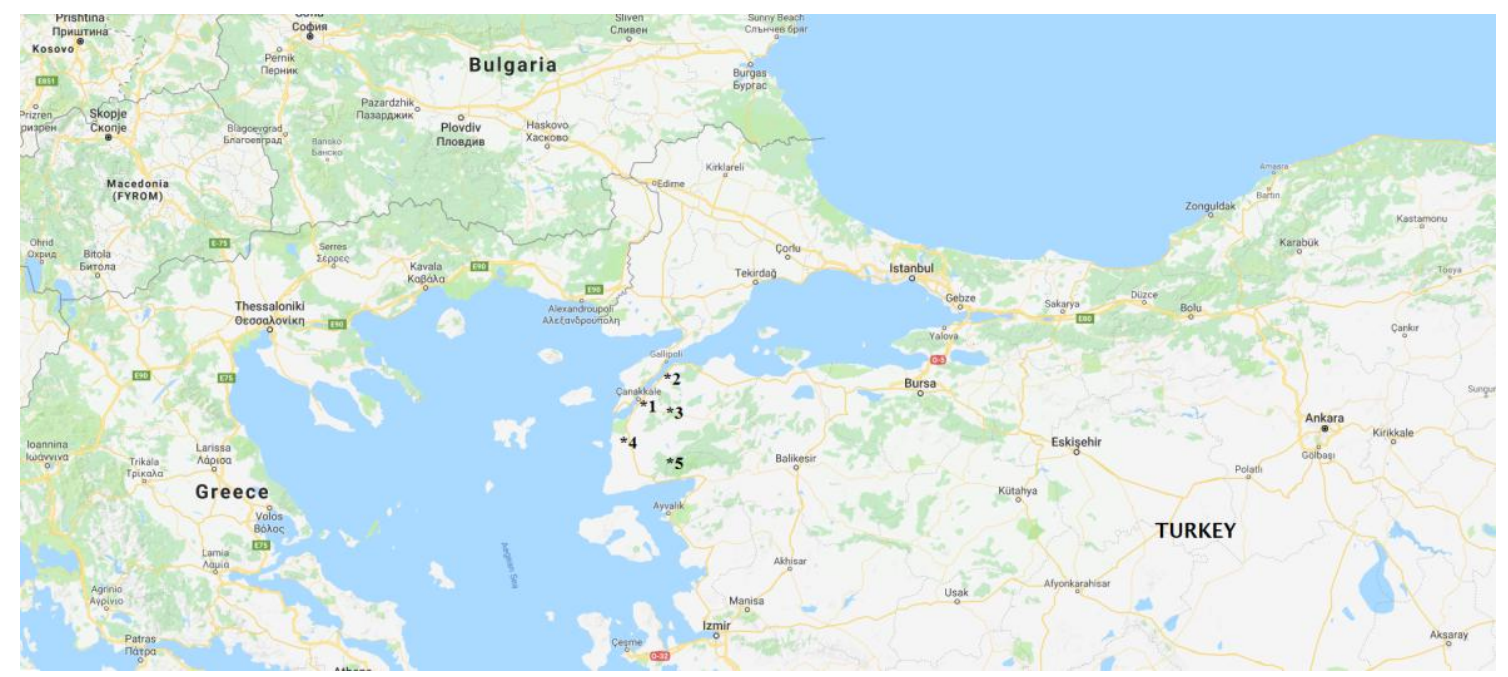

Figure 1. Map of study area. 1-City Center, 2-Lapseki, 3-Çan, 4-Ezine, 5-Bayramiç (source: https://maps.google.com) 
A total of 20 specimens were collected manually in two different periods; 11 ( $7 \widehat{\partial} \widehat{\partial}$, 4 우) in the pre-reproduction period (March and April 2016) and 9 (5 $\widehat{\delta}, 4$ 우) in reproduction period (June and July 2016) in forested areas, through the bushes and the open areas. All the procedures on the samples were made with the permission of Çanakkale Onsekiz Mart University, Animal Experiments Ethics Committee with the decision numbered 2015/108. Morphological measurements were made with digital caliper and tortometer. After the samples were brought to the laboratory and the necessary blood samples were taken, the tortoises were left behind in the habitats from which they were collected.

For plasma biochemistry analysis, $0.5 \mathrm{ml}$ blood was taken with a $5 \mathrm{ml}$ scaled syringe on the right or left side of the ligament in the jugular vein on the neck (Wright, 2008). Blood samples were transferred to biochemical tubes containing lithium heparin (BD Vacutainer, Becton Dickinson, Plymouth, UK). The blood was centrifuged at $4000 \mathrm{rpm}$ for 10 minutes in a centrifuge, and the plasma part was separated. Biochemical parameters (glucose, urea, calcium, cholesterol, triglyceride, creatinine, uric acid, total protein, iron, albumin, phosphorus, H.D.L. and magnesium) to be studied were obtained by measuring with ELIMAT brand auto analyzer using commercial kit in the obtained plasma. For hematocrit analysis, blood was taken into micro hematocrit tubes and centrifuged at $1000 \mathrm{rpm}$ for 5 minutes in a micro hematocrit centrifuge and micro hematocrit tubes were calculated with hematocrit paper and the result was found as $\%$. Total hemoglobin concentration was measured colorimetrically with a sahli hemoglobinometer (Tanyer, 1985).

Descriptive statistics of plasma biochemistry parameters were evaluated using SPSS (20.0 for Windows Student Version) statistical program. Statistical comparison was made using the Mann Whitney U test in the SPSS program.

\section{Results}

In this study, morphological measurements were taken from the samples and similar sized samples were used. The carapace lengths of specimens were measured as about $16.14 \mathrm{~cm}$ in male individuals and about $20.37 \mathrm{~cm}$ in female individuals. In this study, plasma biochemical values were examined separately in female and male individuals in pre-reproduction and reproduction period, and the data pertaining to a total of 15 parameters are given in Table 1.

Table 1. Plasma biochemical values of T. graeca species pre-reproduction and reproduction periods. N: sample number, Min-Max: minimum-maximum values, SD: standard deviation

\begin{tabular}{|c|c|c|c|c|c|c|c|c|c|}
\hline \multirow[b]{2}{*}{ PARAMETERS } & \multirow[b]{2}{*}{ Sex } & \multicolumn{4}{|c|}{ PRE-REPRODUCTION PERIOD } & \multicolumn{4}{|c|}{ REPRODUCTION PERIOD } \\
\hline & & $\mathrm{N}$ & Min-Max & Mean & SD & $\mathrm{N}$ & Min-Max & Mean & SD \\
\hline \multirow{3}{*}{$\begin{array}{l}\text { Glucose * } \\
\text { mg/dL }\end{array}$} & कर & 7 & $24.87-198$ & 134.02 & 55.90 & 5 & $61.7-143.3$ & 82.63 & 34.34 \\
\hline & 아 & 3 & $121.3-166.7$ & 144.86 & 22.74 & 3 & $71.39-86.01$ & 79.35 & 6.05 \\
\hline & $\overline{0} \delta^{\lambda}+q$ 우 & 10 & $24.87-198$ & 137.27 & 47.18 & 8 & $61.70-143.3$ & 81.17 & 24.62 \\
\hline \multirow{3}{*}{$\begin{array}{l}\text { Urea } \\
\mathrm{mg} / \mathrm{dL}\end{array}$} & $\hat{0} \sigma^{\pi}$ & 7 & $9.7-46.12$ & 21.36 & 11.93 & 5 & $11.5-81.40$ & 32.40 & 28.49 \\
\hline & 우 & 4 & $15.00-85.6$ & 50.57 & 30.61 & 4 & $12.9-86.70$ & 32.92 & 35.90 \\
\hline & $\overline{0} \hat{0}+q$ + & 11 & $9.70-85.60$ & 31.98 & 24.16 & 9 & $11.5-86.7$ & 32.63 & 29.82 \\
\hline \multirow{3}{*}{$\begin{array}{c}\text { Cholesterol * } \\
\text { mg/dL }\end{array}$} & $\hat{\partial} \sigma^{\lambda}$ & 6 & $166.3-386$ & 266.13 & 83.03 & 5 & $22.35-130.1$ & 76.69 & 45.37 \\
\hline & 우우 & 4 & $94.2-623.7$ & 247.6 & 252.57 & 4 & $79.49-208.6$ & 136.75 & 64.77 \\
\hline & $\hat{0} \hat{\delta}^{2}+$ 우우 & 10 & $94.2-623.7$ & 258.72 & 158.7 & 9 & $22.35-208.6$ & 103.38 & 60.03 \\
\hline
\end{tabular}




\begin{tabular}{|c|c|c|c|c|c|c|c|c|c|}
\hline \multirow{3}{*}{$\begin{array}{c}\text { Creatinine } \\
\text { mg/dL }\end{array}$} & $0 \pi$ & 7 & $0.1-0.6$ & 0.43 & 0.16 & 5 & 0.24-0.49 & 0.34 & 0.098 \\
\hline & 우우 & 4 & $0.2-0.73$ & 0.45 & 0.24 & 4 & $0.1-0.38$ & 0.23 & 0.12 \\
\hline & $\hat{0} \widehat{o}+q+q$ & 11 & $0.1-0.73$ & 0.44 & 0.18 & 9 & $0.1-0.49$ & 0.29 & 0.11 \\
\hline \multirow{3}{*}{$\begin{array}{l}\text { Uric Acid * } \\
\text { mg/dL }\end{array}$} & $0^{2} 0^{2}$ & 5 & $0.35-1.07$ & 0.68 & 0.35 & 5 & $0.25-6.31$ & 3.29 & 2.59 \\
\hline & 우우 & 4 & $0.55-1.30$ & 0.83 & 0.12 & 4 & $1.28-7.82$ & 4.38 & 3.30 \\
\hline & 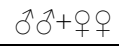 & 9 & $0.35-1.07$ & 0.68 & 0.27 & 9 & $0.25-7.82$ & 3.78 & 2.79 \\
\hline \multirow{3}{*}{$\begin{array}{c}\text { Albumin } \\
\text { g/dL }\end{array}$} & कें & 7 & $1.25-2.8$ & 1.59 & 0.56 & 4 & $0.85-1.59$ & 1.22 & 0.33 \\
\hline & 우우 & 4 & $0.45-2.14$ & 1.31 & 0.83 & 4 & $0.4-2.06$ & 1.33 & 0.69 \\
\hline & 숭ㅎ+우우 & 11 & $0.45-2.8$ & 1.49 & 0.65 & 8 & $0.4-2.06$ & 1.27 & 0.50 \\
\hline \multirow{3}{*}{$\begin{array}{c}\text { Calcium } \\
\text { mg/dL }\end{array}$} & $\hat{0} 0^{\pi}$ & 6 & $3.6-9.91$ & 7.02 & 2.45 & 5 & $6.96-30.20$ & 15.16 & 10.38 \\
\hline & 우우 & 4 & $2.63-38.61$ & 15 & 16.26 & 4 & $1.07-25.13$ & 16.29 & 10.87 \\
\hline & $\hat{0} \hat{0}+\hat{+}+9$ 우 & 10 & $2.63-38.61$ & 10.21 & 10.41 & 9 & $1.07-30.20$ & 15.66 & 9.93 \\
\hline \multirow{3}{*}{$\begin{array}{l}\text { Triglyceride } \\
\text { mg/dL }\end{array}$} & $\hat{0} \hat{0}$ & 6 & $111-673.5$ & 366.55 & 203.33 & 4 & $121.30-743.7$ & 384.75 & 278.14 \\
\hline & 우우 & 4 & $105.6-276.7$ & 185.47 & 70.24 & 4 & $84.10-309.3$ & 202.70 & 92.20 \\
\hline & $\hat{0} \hat{0}+q+q$ & 10 & $105.6-673.5$ & 294.12 & 182.64 & 8 & $84.10-743.7$ & 293.72 & 215.10 \\
\hline \multirow{3}{*}{$\begin{array}{l}\text { T.Protein } \\
\text { g/dL }\end{array}$} & $\hat{0} 0^{\pi}$ & 6 & $2.27-8.64$ & 6.21 & 2.39 & 5 & $0.22-12.31$ & 6.29 & 3.83 \\
\hline & 우우 & 4 & $1.02-7.76$ & 4.68 & 3.45 & 4 & $4.82-10.80$ & 6.75 & 2.77 \\
\hline & 훙ㅎ+우우 & 10 & $1.02-8.64$ & 5.75 & 2.65 & 9 & $0.22-12.31$ & 6.49 & 3.21 \\
\hline \multirow{3}{*}{$\begin{array}{c}\text { Phosphorus } \\
\text { mg/dL }\end{array}$} & $\widehat{\partial} \hat{\sigma}^{-1}$ & 7 & $0.37-10.33$ & 2.80 & 3.46 & 5 & $0.19-2.19$ & 1.40 & 0.88 \\
\hline & 우 & 4 & $0.3-4.88$ & 2.44 & 1.94 & 4 & $0.17-4.20$ & 2.05 & 1.65 \\
\hline & 훙ㅎ+우우 & 11 & $0.3-10.33$ & 2.67 & 2.89 & 9 & $0.17-14.20$ & 1.69 & 1.23 \\
\hline \multirow{3}{*}{$\begin{array}{l}\text { Magnesium } \\
\text { mg/dL }\end{array}$} & $\hat{\partial}$ & 6 & $0.07-5.27$ & 1.30 & 1.98 & 5 & $0.2-0.83$ & 0.45 & 0.27 \\
\hline & 우우 & 4 & $0.91-1.13$ & 0.98 & 0.1 & 4 & $0.1-1.19$ & 0.68 & 0.50 \\
\hline & $\hat{0} \overline{0}+q 0+$ & 10 & $0.07-5.27$ & 1.20 & 1.57 & 9 & $0.1-1.19$ & 0.55 & 0.38 \\
\hline \multirow{3}{*}{$\begin{array}{l}\text { H.D.L } \\
\text { mg/dL }\end{array}$} & के & 7 & $31.52-207$ & 86.94 & 59.71 & 5 & $5.03-52.17$ & 32.59 & 20.49 \\
\hline & 우우 & 4 & $39.75-148$ & 88.24 & 51.37 & 4 & $24.31-106.2$ & 64.73 & 43.59 \\
\hline & $\widehat{3} \hat{0}++9+9+$ & 11 & $31.52-207$ & 87.41 & 54.14 & 9 & $5.03-106.2$ & 46.88 & 34.78 \\
\hline \multirow{3}{*}{$\begin{array}{l}\text { Iron * } \\
\text { g/dL }\end{array}$} & $\partial^{\lambda}$ & 6 & $69.8-346.7$ & 179.53 & 106.46 & 5 & $87.6-244.8$ & 176.28 & 60.06 \\
\hline & 우우 & 4 & $15.2-89.7$ & 45.92 & 33.16 & 4 & 94.9-288.9 & 150.75 & 92.58 \\
\hline & 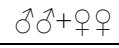 & 10 & $15.2-346.7$ & 126.9 & 106.88 & 9 & $87.6-288.9$ & 164.93 & 72.10 \\
\hline \multirow{3}{*}{$\begin{array}{c}\text { Hemoglobin } \\
\text { g/dL }\end{array}$} & $\partial \hat{O}$ & 6 & 5-11 & 7.36 & 2.20 & 5 & $5-8.4$ & 7.24 & 1.39 \\
\hline & 우우 & 4 & $6-6.8$ & 6.47 & 0.35 & 4 & $6-8$ & 7.1 & 0.84 \\
\hline & ${ }^{2} \hat{o}^{2}+$ 우우 & 10 & $5-11$ & 7.01 & 1.72 & 9 & $5-8.4$ & 7.17 & 1.11 \\
\hline \multirow{3}{*}{$\begin{array}{c}\text { Hematocrit } \\
\text { (PCV) } \\
\%\end{array}$} & $\partial \widehat{0}$ & 7 & $0.15-0.35$ & 0.22 & 0.08 & 5 & $0.13-0.3$ & 0.24 & 0.069 \\
\hline & 우운 & 4 & $0.16-0.33$ & 0.21 & 0.076 & 4 & $0.18-0.25$ & 0.23 & 0.035 \\
\hline & $\widehat{\jmath} \hat{\jmath}+q q$ & 11 & $0.15-0.35$ & 0.22 & 0.07 & 9 & $0.13-0.3$ & 0.24 & 0.054 \\
\hline
\end{tabular}

* P value of less than 0.05 indicates significant difference between the compared means.

When comparing the pre-reproductive period and the reproductive period in terms of glucose, uric acid and iron values, statistical differences were found in the females. It was determined that cholesterol values of males were significantly different between periods. In the females, glucose value was found high in the pre-reproductive period and uric acid and iron values were high in the reproductive period. Cholesterol values of males were found high in the pre-reproductive period. In addition, there was statistical difference between iron values of males and females in the pre-reproductive period. 


\section{Discussion}

\section{Glucose}

In our glucose values, when females were compared, it was found that there was a statistically significant difference in glucose between pre-reproduction period and reproduction period (P: 0.034; $\mathrm{U}: 0.000 ; \mathrm{Z}:-2.121)$. When male and female individuals were evaluated together, there were significant differences between the two periods ( $\mathrm{P}$ : 0.007 ; U: 12.00; Z: -2.694). In both sexes, glucose levels were found to be higher in the pre-reproduction period than in the reproduction period. It is thought that there is an increase after hibernation because the animal that is wakened from winter sleep fed too much to be prepared for the reproduction period. Hamooda et al. (2014) found that glucose values in the $T$. graeca specimens were close to each other in females and males.

\section{Urea}

In our urea values, no statistically significant difference was found between the sexes in the periods. Gilles-Baillien (1969) determined the urea value of T. hermanni as 2.46 $\mathrm{mg} / \mathrm{dL}$ and found that the urea concentration increased when preparing for winter sleep.

\section{Cholesterol}

In our cholesterol values for males, when pre-reproduction and reproduction period were compared, it was determined that there is a significant difference (P: 0.006; U: $0.000 ; \mathrm{Z}:-2.739)$. When male and female individuals are evaluated together, there are significant differences between the two periods (P: 0.007; U: 12.00; Z: -2.694). The cholesterol values obtained in both genders in the pre-reproduction period are higher than in the reproduction period. Hamooda et al. (2014) reported that cholesterol in T. graeca was significantly higher in females during the season in which they were active, and varied by season. These observations and analyzes have shown that there is a close relationship between egg development and vitellogenesis (Christopher et al., 1999, Hidalgo-Vila et al., 2007). And they have shown that testosterone hormone has a negative correlation with cholesterol.

\section{Albumin}

In our albumin values, there were no significant differences in pre-reproduction period and reproduction period, and similar values were determined. Dickinson et al. (2002) found that sex, location, and period cause significant differences in hematology and blood biochemistry in the desert turtle Gopherus agassizii, they found that there was no difference between the male and female individuals in albumin values. In our values, no statistically significant difference was found between the sexes in both periods.

\section{Calcium}

There was no statistic difference between the sex and periods in terms of the calcium parameter. Marks and Citino (1990) found that plasma vitelline causes an increase in the amount of calcium present during the reproduction period in the Testudo radiata specimens. And they found that calcium levels were not significantly different between males and females. 


$$
-3310-
$$

\section{Creatinine}

In our creatinine values, there were no significant differences in pre-reproduction period and reproduction period, and close values were determined. There was no difference between the sexes in both periods. Hamooda et al. (2014) reported that creatinine values of $T$. graeca were found close to each other in males and females. There was no statistically significant difference in the creatinine values of $T$. hermanni, periodically in both sexes (Özdamar, 2014).

\section{Total protein}

There was no significant difference in pre-reproduction period and reproduction period, and close values were determined. There was no statistic difference between the sexes in both periods. In $G$. polyphemus, serum total protein levels were found to be higher in females compared to males (Taylor and Jacobson, 1982). Özdamar (2014) reported that the pre-reproduction period in T. hermanni species was shorter in females than in males.

\section{Uric acid}

There was no statistic difference between the sexes in both periods. It was determined that uric acid value in females was statistically different when pre-reproduction period and reproduction period were compared (P: 0.034; U: 0.000; Z: -2.121). When male and female individuals were evaluated together, there were significant differences between the two periods (P: 0.007; U: 8.000; Z: -2.694). It was determined that the uric acid levels in both sexes were lower in the pre-reproduction period than in the reproductive period. Scope et al. (2013) found that the concentration of uric acid in the T. hermanni specimens was the highest after winter hibernation. The lowest values were found to be $0.9 \mathrm{mg} / \mathrm{dL}$ in October and the highest value was found to be $5.4 \mathrm{mg} / \mathrm{dL}$ after winter sleep.

\section{Phosphorus}

In our phosphorus values, there were no significant statistical differences in the prereproduction period and reproduction period, but they were observed to be lower in reproduction period. Phosphorus was found to have no effect on sex. By Scope et al. (2013), phosphorus values of T. hermanni were found to be higher in females than in males and the maximum value for phosphorus was seen at the earliest in June.

\section{Magnesium}

There were no statistical differences between the sexes and the periods. Hamooda et al. (2014) found magnesium in $T$. graeca as $5.33 \mathrm{mg} / \mathrm{dL}$ in females and $5.64 \mathrm{mg} / \mathrm{dL}$ in males.

\section{Triglycerides}

In our triglyceride values, there was no statistical difference. Hamooda et al. (2014) observed that the concentration of triglycerides in female $T$. graeca showed a significant increase when compared to males. 


\section{Iron}

In our iron values, a significant difference was found between males and females in pre-reproduction period ( $\mathrm{P}: 0.019 ; \mathrm{U}: 1.000 ; \mathrm{Z}:-2.345)$. When the female individuals were compared between the pre-reproduction and the reproduction period, the statistical difference was observed (P: 0.021; U: 0.000; Z: -2.309). A detailed study on the reference intervals of the iron values of tortoises has not been found.

\section{HDL cholesterol}

There was no statistical difference between the sexes and the periods. Sex and size were found to influence the biochemical parameters of HDL-cholesterol (Whiting et al., 2007; Anderson et al., 2011). Mader and Divers (2013) reported that in reptiles; females had high cholesterol during active laying period.

\section{Hematocrit}

In our hematocrit values, there was no statistical difference between the two periods and sexes. Hamooda et al. (2014) suggested that low levels of hematocrit in the T. graeca species are related to sexual affect. Tosunoğlu et al. (2005) found hematocrit values between $21-34 \%$ for $T$. hermanni and $24-36 \%$ for $T$. graeca species. They noted that hematocrit value is potentially informative about the state and physiology of the tortoises.

\section{Hemoglobin}

In our hemoglobin parameters, there was no statistical difference between the two periods and sexes. Tosunoğlu et al. (2005) reported hemoglobin levels of 4.9-7.4 g/dL for T. hermanni and 5.2-9.7 g/dL for T. graeca. Hamooda et al. (2014) found that the concentration of hemoglobin in the $T$. graeca species was characterized by low average values in both males and females, which have a significant effect in favor of male tortoises.

\section{Conclusion}

Biochemical analyses of blood plasma are an important method for assessing the health of many animal species. For this reason, comparative hematological results of $T$. graeca, which is on the Red List of the IUCN in the Vulnerable category, are given in this study. The data of this study will be useful for evaluating future health problems and for species conservation studies.

Acknowledgements. This study is a part of the author's master's thesis.

\section{REFERENCES}

[1] Anderson, E.T., Minter, L.J., Clarke, E.O., Mroch, R.M., Beasley, J.F., Harms, C.A. (2011): The Effects of Feeding on Hematological and Plasma Biochemical Profiles in Green (Chelonia mydas) and Kemp's Ridley (Lepidochelys kempii) Sea Turtles. - Vet. Med. Int. 1-7. 
[2] Bielli, M., Nardini, G., Di Girolamo, N., Savarino, P. (2015): Hematological values for adult eastern Hermann's tortoise (Testudo hermanni boettgeri) in semi-natural conditions. - J. Vet. Diagn. Invest. 27(1): 68-73.

[3] Christopher, M.M., Berry, K.H., Wallis, I.R., Nagy, K.A., Henen, B.T., Peterson, C.C. (1999): Reference intervals and Physiologic Alterations in Hematologic and Biochemical Values of Free-Ranging Desert Tortoises in the Mojave Desert. - J. Wildl. Dis. 35: 212238.

[4] Dickinson, V.M., Jarchow, J.L., Trueblood, M.H. (2002): Hematology and Plasma Biochemistry Reference Range Values for Free-Ranging Desert Tortoises in Arizona. - J. Wildl. Dis. 38 (1): 143-153.

[5] Gilles-Baillien, M. (1969): Seasonal Variationsin Blood and Urine Constituents of the Tortoise (Testudo hermanni hermanni) Gmelin. - Arch. Int. Physiol. Biochim. 77: 427440.

[6] Godfrey, M.H., Campbell, L.M. (2002): Turtle Conservation. - Marine Turtle Newsletter 98: 20-22.

[7] Hamooda, E.A.F., El-Mansoury, A.M., Mehdi, A.R. (2014): Some Blood Indexes of the Tortoise Testudo graeca Linnaeus 1758, From Benghazi Province, Libya. - Sci. R. J. 2(9): 36-44.

[8] Hetenyi, N., Satorhelyi, T., Kovacs, S., Hullar, I. (2016): Variations in Blood Biochemical Values in Male Hermann's Tortoises (Testudo hermanni). - Veterinaria 65 (1): $15-21$.

[9] Hidalgo-Vila, J., Diaz-Paniagua, C., Perez-Santigosa, N., Plaza, A., Camacho, I., Recio, F. (2007): Hematologic and Biochemical Reference Intervals of Free-Living Mediterranean Pond turtles (Mauremys leprosa). - J. Wildl. Dis. 43 (4): 798-801.

[10] Jacobson, E.R., Gaskin, J.M., Brown, M.B., Harris, H.K., Gardiner, C.H., Lapointe, J.L., Adams, H.P., Reggiardo, C. (1991): Chronic Upper Respiratory Tract Disease of FreeRanging Desert Tortoises (Xerobates agasizii). - J. Wildl. Dis. 27: 296-316.

[11] Lopez-Olvera, J.R., Montane, J., Marco, I., Martinez-Silvestre, A., Soler, J., Lavin, S. (2003): Effect of Venipuncture Site on Hematologic and Serum Biochemical Parameters in Marginated Tortoýse (Testudo marginiata). - J. Wildl. Dis. 39 (4): 830-836.

[12] Mader, D.R., Divers, S.J. (2013): Current Therapy in Reptile Medicine and Surgery. Elsevier Saunders. 1-488.

[13] Marks, S.T., Citino, S.B. (1990): Hematology and Serum Chemistry of the Radiated Tortoise (Testudo radiata). - J. Zoo. Wildl. Med. 21: 342-344.

[14] Özdamar, D. (2014): Trakya Bölgesi'nde Dağılış Gösteren Testudo hermanni (Testudinata; Testudinidae) Populasyonlarında Plazma Biyokimyasına ait Parametrelerin Belirlenmesi. (in Turkish) - Çanakkale Onsekiz Mart Üniversitesi Yüksek Lisans Tezi, 142.

[15] Raphael, B.L., Klemens, M.W., Moehlman, P., Dierenfeld, E., Karesh, W.B. (1994): Blood Values in Free-Ranging Pancake Tortoises (Malacochersus tornieri). - J. Zoo. Wildl. Med. 25:63-67.

[16] Scope, A., Schwendenwein, I., Schauberger, G. (2013): Characterization and Quantification of the influence of Season and Gender on Plasma Chemistries of Hermann's Tortoises (Testudo hermanni, Gmelin 1789). - Res. Vet. Sci. 95: 59-68.

[17] Tanyer, G. (1985): Hematology and Laboratory. (in Turkish) - Ayyıldız Matbaası A.Ş. Ankara. 442 p.

[18] Taylor, R.W., Jacobson, E.R. (1982): Hematology and Serum Chemistry of the Gopher Tortoise Gopherus polyphemus. - Comp. Biochem. Physiol. 72A: 425-428.

[19] Tosunoğlu, M., Tok, C.V., Gül, Ç. (2005): Hematological Values in Hermann's Tortoise (Testudo hermanni) and Spur-thigted Tortoise (Testudo graeca) from Thrace Region (Turkey). - International Journal of Zoological Research. 1 (1): 11-14.

[20] Tosunoğlu, M., Gül, Ç., Uysal, İ. (2017): Çanakkale Amfibi ve Sürüngenleri. (in Turkish) - Özen reklam, Turkey, ISBN 978-605-82906-1-7. 72 p. 


$$
-3313-
$$

[21] Whiting, S.D., Guinea, M.L., Limpus, C.J., Fomiatti, K. (2007): Blood Chemistry Reference Values for Two Ecologically Distinct Populations of Foraging Green Turtles, Eastern Indian Ocean. - Comp. Clin. Path. 16:109-118.

[22] Wright, K. (2008): Diagonistic Sampling and Other Procedures with Turtles and Tortoises. - Exotic-Reptiles book, 1801-1803. 